\title{
UPAYA MENINGKATKAN HASIL BELAJAR PESERTA DIDIK DENGAN MENGGUNAKAN MODEL PEMBELAJARAN CONTEXTUAL TEACHING AND LEARNING (CTL) PADA MATA PELAJARAN ILMU PENGETAHUAN ALAM TENTANG MATERI CAHAYA DAN SIFAT-SIFATNYA DI KELAS V SD KATOLIK SANTO IGNATIUS MEDAN TAHUN PELAJARAN 2016-2017
}

\section{OLEH: \\ HOTDIANA BUATON \\ (PGSD FKIP UNIVERSITAS KATOLIK SANTO THOMAS SU)}

\begin{abstract}
This research is a Classroom Action Research (PTK) which aims to know the implementation of learning and improve student learning outcomes by using the Contextual Teaching and Learning (CTL) learning model in the subjects of Natural Sciences (IPA) with light matter and its properties in Class V SD Santo Catholic Santo Ignatius MedanLesson 2016-2017.Subjects in this study were the students of grade V SD Santo Catholic. Ignatius Medan Lessons Year 2016-2017 which amounted to 40 people, consisting of 20 female students and 18 male students. The object of this research is Classroom Action Research (PTK) by applying two cycles that are Cycle I and Cycle II which includes planning, implementation, observation, and reflection. The results of this study indicate an increase in student learning outcomes in the subjects of Natural Science (IPA) light material and the nature of class V SD Santo Catholic Santo Ignatius Medan. This is evident from the results of research conducted on the pretest of students who got the complete value of 4 people or $10 \%$ while 36 students who did not complete or $90 \%$. Then continued the research on the first cycle of students who got the complete value of 18 students or $45 \%$ while the students who did not complete as many as 22 students or $55 \%$, then there is an increase in the first cycle compared to the preteSanto However, it has not met the completeness category that has been specified. Then proceeded on the second cycle of students who got a total score of 34 students or $85 \%$ while students who are not complete as many as 6 students or $15 \%$, then there is an increase in cycle II compared to cycle I and has fulfilled the specified completeness. Furthermore, teacher activity on observation cycle I get an average of 58\% and in cycle II has increased to $90 \%$. While the activity of students on the learning process obtained an average of $58 \%$ and in cycle II has increased to $81,3 \%$. Thus, it is concluded that by using Contextual Teaching and Learning (CTL) learning model on Natural Science subject (IPA) light material and its properties in class V SD Santo Ignatius Medan can improve student learning outcomes. Therefore it is suggested for subsequent learning to use problem-based learning strategies so that student learning outcomes can increase.
\end{abstract}

Keywords:Student Learning Outcomes, Natural Science Subject (IPA), Contextual Teaching and Learning (CTL) Learning Model.

\section{PENDAHULUAN}

\section{Latar Belakang Masalah}

Menurut Undang-Undang No. 20 Tahun 2003 tentang sistem Pendidikan Nasional bahwa tujuan Pendidikan Nasional adalah untuk mengembangkan potensi siswa agar menjadi manusia yang beriman dan bertaqwa kepada Tuhan Yang Maha Esa, berakhlak mulia, sehat, kreatif, mandiri dan menjadi warga Negara yang demokratis 
serta bertanggung jawab. Pendidikan tersebut merupakan suatu keharusan bagi manusia karena pada hakikatnya manusia lahir dalam keadaan tidak berdaya, tidak langsung dapat berdiri sendiri, dan tidak dapat memelihara dirinya sendiri, sehingga pendidikan dipandang sangat penting dan dibutuhkan oleh setiap manusia karena dengan pendidikan manusia akan memiliki pengetahuan, kemampuan dan kepribadian yang berkembang. Pendidikan dapat membimbing generasi muda untuk mencapai suatu kondisi yang lebih baik dan dapat meningkatkan kesejahteraan hidup. Elmubarok (2009: 3) "pendidikan adalah usaha atau proses yang ditujukan untuk membina kualitas sumber daya manusia seutuhnya agar ia dapat melakukan perannya dalam kehidupan secara fungsional dan optimal.

Sebaliknya, Poerbakawatja dan Harahap (Sagala, 2008: 3) mengatakan bahwa "pendidikan meliputi semua perbuatan dan usaha dari generasi tua untuk mengalihkan pengetahuannya, pengalamannya, kecakapannya dan keterampilannya kepada generasi muda sebagai usaha menyiapkannya agar dapat memenuhi fungsi hidupnya baik jasmaniah maupun rohaniah. Artinya pendidikan adalah usaha secara sengaja dari orang dewasa untuk dengan pengaruhnya meningkatkan si anak ke kedewasaan yang selalu diartikan mampu menimbulkan tanggung jawab moril dari segala perbuatannya".

Selanjutnya (Slameto, 2010:54-60) mengatakan bahwa "pendidikan di sekolah merupakan usaha sadar dan disengaja oleh guru untuk membuat siswa belajar secara aktif dalam mengembangkan kreatifitas berpikirnya. Tujuan pokok dari penyelenggaraan pendidikan tersebut adalah membelajarkan siswa agar mampu memproses dan memperoleh pengetahuan, keterampilan dan sikap bagi diri sendiri".

Menurut Burton (Usman, 2010: 6) mengajar merupakan "suatu perbuatan yang memerlukan tanggung jawab moral yang cukup berat. Berhasilnya pendidikan pada siswa sangat bergantung pada pertanggungjawaban guru dalam melaksanakan tugasnya. Mengajar merupakan suatu pekerjaan yang bersifat unik tetapi sederhana. Dikatakan unik karena hal itu berkenaan dengan manusia yang belajar, yakni siswa, dan yang mengajar, yakni guru, dan berkaitan erat dengan manusia didalam masyarakat yang semuanya menunjukkan keunikan. Dikatakan sederhana karena mengajar dilaksanakan dalam keadaan praktis dalam kehidupan sehari-hari, mudah dihayati oleh siapa saja".

Belajar menurut pandangan Skinner (Sagala, 2008: 14) adalah suatu proses adaptasi atau penyesuaian tingkah laku yang berlangsung secara progresif. Belajar juga dipahami sebagai suatu perilaku, pada saat orang belajar, maka responnya menjadi baik. Sebaliknya jika ia tidak belajar, maka responnya menurun. Jadi belajar ialah suatu perubahan dalam kemungkinan atau peluang terjadinya respons. Seorang anak belajar sungguh-sungguh dengan demikian pada waktu ulangan siswa tersebut dapat menjawab semua soal dengan benar. Atas hasil belajarnya yang baik itu dia mendapatkan nilai yang baik, karena mendapatkan nilai yang baik ini, maka anak akan belajar lebih giat lagi.

Menurut pendapat peneliti, mengajar dan belajar adalah dua hal yang tidak dapat dipisahkan, guru memegang peranan penting dalam pembelajaran di kelas. Tetapi jika tidak ada peserta didik, guru pun tidak ada. Guru tidak bisa mengajar tanpa peserta didik, tetapi peserta didik bisa belajar tanpa ada guru. Itulah sebabnya didalam pendidikan formal guru dengan peserta didik sama-sama saling melengkapi. Peran guru di ruangan kelas bukan hanya menjadi penyaji pelajaran yang akan dipelajari oleh peserta didik, melainkan mengajarkan juga kepada peserta didik tentang cara mempelajari sesuatu dengan efektif. Selain itu, juga harus dapat membimbing dan melatih peserta didik untuk mengembangkan keterampilan yang dimiliki peserta didik tersebut. 
Untuk pendidikan yang bermutu maka dibutuhkan seorang pendidik atau guru. Hamruni (2013:11) "guru adalah pelaku pembelajaran, sehingga dalam hal ini guru merupakan faktor yang terpenting". Selanjutnya Sanjaya (2011:21) "peran utama guru di sekolah adalah menyampaikan ilmu pengetahuan sebagai warisan kebudayaan masa lalu yang dianggap berguna sehingga harus dilestarikan".

Sanjaya (2011:52) "guru merupakan faktor yang berpengaruh terhadap sistem pembelajaran karena guru adalah komponen yang sangat menentukan dalam implementasi suatu strategi pembelajaran. Tanpa guru, bagaimanapun bagus dan idealnya suatu strategi, maka strategi itu tidak mungkin bisa diaplikasikan".

"Di dalam UU No. 20 Tahun 2003 Tentang Sistem Pendidikan Nasional (Sisdiknas), peserta didik didefinisikan sebagai setiap manusia yang berusaha mengembangkan potensi diri melalui proses pembelajaran pada jalur pendidikan baik pendidikan formal maupun pendidikan nonformal, pada jenjang pendidikan dan jenis pendidikan tertentu. Peserta didik juga dapat didefinisikan sebagai orang yang belum dewasa dan memiliki sejumlah potensi dasar yang masih perlu dikembangkan. Potensi dimaksud umumnya terdiri dari tiga kategori, yaitu kognitif, afektif, dan psikomotorik (Danim, 2010: 5)".

Berdasarkan pendapat tersebut, guru merupakan orang yang memberikan ilmu pengetahuan kepada anak didik dan bertanggungjawab untuk mendidik, mengajar, membimbing, mengarahkan dan menilai anak didiknya. Karena itu, tanpa guru bagaimanapun bagus dan idealnya suatu strategi, maka strategi itu tidak mungkin bisa lakukan.

Hamruni (2013:11) "peserta didik merupakan komponen yang melakukan kegiatan belajar untuk mengembangkan potensi kemampuan menjadi nyata guna mencapai tujuan belajar." Selanjutnya, Sanjaya (2011:54) "peserta didik merupakan faktor yang berpengaruh terhadap sistem pembelajaran karena Peserta didik merupakan organisme yang unik yang berkembang sesuai dengan tahap perkembangannya".Penulis berpendapat bahwa peserta didik merupakan seseorang yang berusaha mengembangkan potensi diri melalui proses pembelajaran baik formal, informal maupun nonformal.

Samatowa, (2016:19)"Ilmu Pengetahuan Alam (IPA) merupakan salah satu ilmu yang mempelajari tentang gejala-gejala alam. IPA juga merupakan bagian dari ilmu pengetahuan yang terdiri dari fakta-fakta, konsep-konsep, atau prinsip-prisip, dan teoriteori yang merupakan proses ilmiah. Ini berarti IPA mempelajari semua benda yang ada di alam, peristiwa dan gejala-gejala yang muncul di alam. IPA diharapkan menjadi alat atau sarana bagi peserta didik untuk mempelajari alam sekitar dan diri sendiri".

Materi yang akan ditelitidalam penelitian ini yaitutentang cahaya dan sifatsifatnya. Menurut fisikawan Inggris James Clerk Maxwell (Tim Bina Karya Guru, 2006:132) cahaya adalah rambatan gelombang yang dihasilkan oleh gabungan medan listrik dan medan magnet. Gelombang yang dihasilkan dari gabungan medan listrik dan medan magnet tersebut disebutgelombang elektromagnet.Cahaya dibedakan menjadi dua, yaitu cahaya tampak dan cahaya tak tampak. Cahaya tampak adalah cahaya putih yang dapat ditangkap oleh mata kita. Cahaya tak tampak misalnya sinar $\mathrm{X}$, sinar ultraviolet, sinar gamma, dan sinar inframerah.Cahaya memiliki sifat-sifat yaitu:merambat lurus, menembus benda bening, dapat dipantulkan, dapat dibiaskan. Benda bening misalnya air jernih dan gelas bening. Cahaya akan diteruskan sebagian jika mengenai benda keruh. Contoh benda keruh adalah air sabun.

Pembelajaran yang diciptakan guru di dalam kelas hanya sebatas memberikan informasi tentang materi tersebut sehingga peserta didik tidak mengerti atau memahami isi materi yang dijelaskan. Dalam pendidikan sekolah,masalah yang sering ditemui yaitu 
masih rendahnya daya ingat peserta didik yang menyebabkan peserta didik mendapat nilai rata-rata yang masih rendah. Rendahnya kemampuan peserta didik dalam memahami materi, yaitu kurang efektifnya pembelajaran yang dilakukan oleh guru. Keefektifan itu disebabkan kurang tepatnya model pembelajaran yang dilakukan oleh guru. Adapun model pembelajaran yang digunakan oleh guru tidak dapat membuat peserta didik untuk lebih aktif saat proses pembelajaran berlangsung. Ini berarti guru masih menerapkan pembelajaran yang masih berpusat pada guru. Adapun alasan mengapa guru lebih suka menggunakan sistem pembelajaran yang hanya berpusat pada guru, karena sistem pembelajaan tersebut tidak membutuhkan bahan dan alat peraga, cukup hanya membahas materi yang ada pada buku pelajaran.

Berdasarkan hasil observasi dan wawancara dengan guru mata pelajaran IPA materi cahaya dan sifat-sifatnya di kelas V SD Katolik St. Ignatius Medan Tahun Pelajaran 2015-2016 terdapat beberapa masalah, yaitu proses pembelajaran IPA berlangsung hanya sebatas guru meminta siswa membaca teks bacaan pada buku paket, guru menerangkan materi pembelajaran dan kemudian guru memberikan tugas latihan dan tugas rumah. Disamping itu guru tidak menggunakan media pembelajaran proses pembelajaran hanya sebatas papan tulis dan tidak terdapat media lainnya yang dapat mendukung proses pembelajaran, tidak terdapat proses pembelajaran yang menarik seperti diskusi kelompok, sebagaian besar siswa jarang terlibat dalam hal bertanya kepada guru dan jika guru yang bertanya antusias siswa dalam menjawab sangat rendah, bahkan sebagian siswa tidak memperhatikan penjelasan guru.

Selama observasi tersebut banyak siswa yang terlihat tidak bergairah dalam proses pembelajaran IPA dan tidak bersemangat untuk mengerjakan soal-soal latihan. Berdasarkan hasil pengamatan yang dilakukan oleh peneliti, maka diperoleh informasi bahwa hasil belajar IPA belum memperoleh hasil belajar yang maksimal. Hal ini terlihat dari nilai ulangan harian siswa kelas V SD St. Ignatius Medan masih belum mencapai Kriteria Ketuntasan Minimal (KKM) yang telah ditetapkan yaitu 70. Dari 40 orang peserta didik dalam kelas tersebut terdapat 10 (25\%) peserta didik yang memenuhi Kriteria Ketuntasan Minimal (KKM), sedangkan 30 (75\%) peserta didik yang tidak memperoleh nilai KKM. Nilai KKM ini yang sudah ditetapkan oleh sekolah.

Menurut Soekamto (Hamruni, 2013:6) "model pembelajaran adalah kerangka konseptual yang melukiskan prosedur yang sistematis dalam mengorganisasikan pengalaman belajar untuk mencapai tujuan belajar tertentu dan berfungsi sebagai pedoman bagi para perancang pembelajaran dan para pengajar dalam merencanakan aktivitas belajar mengajar".

Berbagai jenis model pembelajaran yang dapat meningkatkan hasil belajar. Salah satunya adalah dengan menggunakan model pembelajaran "contextual teaching and learning”. Model pembelajaran ini baik digunakan untuk mendorong agar peserta didik dapat menemukan hubungan antara materi yang dipelajari dengan situasi kehidupan yang nyata, artiya siswa dituntut untuk dapat menangkap hubungan antara pengalaman belajar di sekolah dengan kehidupan nyata.

Menurut Shoimin ( 2016:41) "contextual teaching and learning merupakan suatu proses pembelajaran yang holistik dan bertujuan memotivasi siswa untuk memahami makna materi pelajaran yang dipelajarinya dengan mengaitkan materi tersebut dengan konteks kehidupan sehari-hari (konteks pribadi, sosial dan kultural) sehingga siswa memiliki pengetahuan/keterampilan yang secara fleksibel dapat diterapkan (ditransfer) dari satu permasalahan ke permasalahan lainnya".Penulis berpendapat bahwa model pembelajaran merupakan strategi yang dilakukan oleh seorang guru dalam melaksanakan kegiatan belajar mengajar agar tujuannya siswa dapat 
memahami peta konsep tentang cahaya,menyebutkan sifat-sifat cahaya, menunjukkan contoh-contoh peristiwa pembiasan cahaya dalam kehidupan sehari-hari dan diharapkan tercapai.

Salah satu penelitian yang relevan dengan penelitian ini yaitu Ajeng Widyaningrum yang berjudul "Meningkatkan hasil belajar siswa pada mata pelajaran IPA dengan menggunakan pendekatan Contextual Teaching and Learning (CTL) di kelas IV SD Negeri 105292 Bandar Klippa T.P 2011/2012.” Dari pemberian tindakan dengan pembelajaran menggunakan pendekatan Contextual Teaching and Learning (CTL). Penelitian ini menggunakan 2 siklus yang manapada tes awal, siklus I dan siklus II diperoleh tingkat ketuntasan belajar siswa. Tingkat ketuntasan belajar siswa secara klasikal mencapai (93\%) yang artinya sudah mencapai tingkat ketuntasan belajar yang diharapkan.

Berdasarkan uraian di atas maka penulis tertarik untuk mengangkat masalah ini sebagai topik penelitian yang berjudul "Upaya Meningkatkan Hasil Belajar Peserta Didik dengan Menggunakan ModelPembelajaran Contextual Teaching and Learning (CTL) pada mata pelajaran IPA tentang cahaya dan Sifat-sifatnya di Kelas V SD Katolik St. Ignatius Medan Tahun Pelajaran 2016-2017."

\section{Identifikasi Masalah}

Berdasarkan uraian latar belakang di atas, maka dapat diidentifikasikan beberapa permasalahan, antara lain :

1. Guru cenderung menggunakan metode ceramah dan penugasan

2. Jumlah siswa yang aktif dalam proses pembelajaran kurang optimal

3. Rendahnya hasil belajar siswa pada mata pelajaran IPA

\section{Pembatasan Masalah}

Berdasarkan identifikasi masalah di atas, ada beberapa masalah sebagai penyebab rendahnya hasil belajar peserta didik. Pada peneliti inipenulis akan membatasi masalah untuk menghindari pembahasan yang terlalu luas.Adapun batasan masalah penelitian ini ialah :

1. Rendahnya hasil belajar peserta didik dalam pembelajaran IPA dengan pokok bahasan cahaya dan sifat-sifatnya di kelas V SD Katolik St. Ignatius, karena model pembelajaran yang diterapkan oleh guru kurang menarik.

2. Guru tidak pernah menerapkan model pembelajaran Contextual Teaching and Learning (CTL) pada materi cahaya dan sifat-sifat.

\section{Rumusan Masalah}

Berdasarkan identifikasi masalah dan pembatasan masalah yang telah diuraikan di atas, maka rumusan masalah dalam penelitian ini adalah:

1. Bagaimana pelaksanaan pembelajaran dengan menggunakan model pembelajaran "Contextual Teaching and Learning" pada mata pelajaran IPA tentang cahaya dan sifat-sifatnya di kelas V SD Katolik St. Ignatius Medan tahun pembelajaran 20162017 ?

2. Apakah Model "Contextual Teaching and Learning" dapat meningkatkan hasil belajar peserta didik pada mata pelajaran IPA tentang cahaya dan sifat-sifatnya di kelas V SD Katolik St. Ignatius Medan tahun pembelajaran 2016-2017?

\section{Tujuan Penelitian}

Berdasarkan permasalahan yang telah dirumuskan di atas, maka tujuan yang ingin dicapai dalam penelitian ini adalah sebagai berikut:

1. Untuk mengetahui pelaksanaan pembelajaran dengan menggunakan model pembelajaran "Contextual Teaching and Learning" pada mata pelajaran IPA tentang 
cahaya dan sifat-sifatnya di kelas V SD Katolik St. Ignatius Medan tahun pembelajaran 2016-2017.

2. Untuk mengetahui Model "Contextual Teaching and Learning” dapat meningkatkan hasil belajar peserta didik pada mata pelajaran IPA tentang cahaya dan sifat-sifatnya di kelas V SD Katolik St. Ignatius Medan tahun pembelajaran 2016-2017.

\section{Manfaat Penelitian}

\section{a. Manfaat Teoritis}

Manfaat teoritis artinya hasil penelitian bermanfaat untuk mengembangkan ilmu pengetahuan. Manfaat teoritis penelitian ini yaitu menambah referensi di bidang pendidikan, terutama dalam meningkatkan hasil belajarpada siswa kelas $\mathrm{V}$ sekolah dasar.

\section{b. Manfaat Praktis}

Manfaat praktis yaitu manfaat yang bersifat praktik dalam pembelajaran. Manfaat praktis penelitian antara lain:

1. Bagi siswa, dengan model pembelajaran kooperatif "Contextual Teaching and Learning” lebih memudahkan siswa memahami materi pelajaran, lebih kreatif, aktif dan dapat menjadi pengalaman belajar yang dapat diterapkan dalam materi pembelajaran lainnya.

2. Bagi guru, dapat meningkatkan pengetahuan dan keterampilan serta membangkitkan rasa percaya diri sehingga bergairah dan semangat untuk memperbaiki cara mengajar yang lebih inovatif dan kreatif sehingga pembelajaran menjadi lebih menyenangkan.

3. Bagi sekolah, membantu sekolah dalam mengembangkan dan menciptakan lembaga pendidikan yang berkualitas dan dapat menjadi contoh bagi sekolah lainnya.

4. Bagi peneliti, menambah wawasan dan pengalaman yang sangat berguna tentang keterampilan mengajar dalam meningkatkan hasil belajar siswa dan menjadi seorang guru profesional nantinya.

\section{METODOLOGI PENELITIAN \\ Pendekatan dan Metode Penelitian}

Dalam penelitian tersebut, peneliti menggunakan pendekatan campuran. Dengan menggunakan pendekatan campuran peneliti dapat memperoleh hasil-hasil statistik kuantitatif dari suatu sampel, kemudian menindaklanjutinya dengan mewawancarai atau observasi sejumlah individu untuk membantu menjelaskan lebih jauh hasil statistik yang diperoleh.

Metode atau jenis penelitian ini menggunakan Penelitian Tindakan Kelas (Classroom Action Research) karena peneliti bertindak secara langsung dalam penelitian, mulai dari awal sampai akhir tindakan. Penelitian ini bertujuan untuk meningkatkan hasil belajar siswa pada pelajaran IPA dengan menggunakan model Contextual Teaching and Learning (CTL) kelas V SD Katolik St. Ignatius Medan.

\section{Tempat dan Waktu Penelitian}

Penelitian dilaksanakan di kelas V SD Katolik St. Ignatius Medan, pada semester genap tahun pembelajaran 2016/2017. Adapun alasan peneliti memilih SD ini adalah:

1. Model pembelajaran Contextual Teaching and Learning (CTL) belum pernah dilaksanakan di SD Katolik St. Ignatius Medan. 
2. Rendahnya hasil belajar peserta didik pada mata pelajaran IPA khususnya materi cahaya dan sifat-sifatnya.

3. Sekolah tersebut bersifat terbuka menerima mahasiswa yang akan melakukan penelitian di SD Katolik St. Ignatius Medan.

\section{Subjek Penelitian}

Subjek penelitian tersebut adalah peserta didik kelas V SD Katolik St. Ignatius Medan, 40 orang yang terdiri dari 22 orang perempuan dan 18 orang laki-laki. Alasan peneliti memilih kelas $\mathrm{V}$ sebagai subjek penelitian adalah hasil observasi dan wawancara dengan guru mata pelajaran IPA. Berdasarkan hasil observasi dan wawancara bahwa guru tersebut belum pernah menggunakan model pembelajaran Contextual Teaching and Learning (CTL) pada mata pelajaran IPA materi Cahaya dan Sifat-sifatnya. Peneliti juga mengamati siswa kurang aktif dalam pembelajaran yang memungkinkan rendahnya nilai pelajaran IPA materi Cahaya dan Sifat-sifatnya.

\section{Jenis dan Sumber Data}

\section{Jenis Data}

Jenis data pada penelitian ini adalah hasil belajar siswa dan aktivitas pendidik. Adapun jenis data yang digunakan dalam penelitian ini adalah kualitatif dan kuantitatif.

a. Data kualitatif

Data kualitatif merupakan metode penelitian yang berlandaskan digunakan untuk meneliti pada kondisi objek yang alamiah, (sebagai lawannya adalah eksperimen), dimana peneliti adalah sebagai instrument kunci, pengambilan sampel sumber (Sugiono, 2015:15).

b. Data kuantitatif

Data kuantitatif merupakan sebagai metode penelitian yang berlandaskan digunakan untuk meneliti pada populasi atau sampel tertentu, teknik pengambilan sampel pada umumnya dilakukan secara random, pengumpulan data menggunakan instrumen penelitian analisis data bersifat kuantitatif/statistic dengan tujuan untuk menguji hipotesis yang telah ditetapkan (Sugiono, 2015:15)

\section{Sumber Data}

a. Informan atau narasumber, yaitu guru mata pelajaran IPA dengan materi cahaya dan sifat-sifatnya kelas V SD St. Ignatius Medan.

b. Tempat dan peristiwa berlangsungnya aktivitas pembelajaran IPAdengan materi cahaya dan sifat-sifatnyadi SD St. Ignatius Medan

c. Dokumen daftar nilai mata pelajaran IPA dengan materi cahaya dan sifat-sifatnyadi kelas V SD St. Ignatius Medan

\section{Teknik dan Alat Pengumpulan Data}

\section{Observasi}

Teknik pengumpulan data dalam penelitian ini adalah berupa obsevasi dan tes.

Observasi adalah teknik mengumpulkan data dengan melakukan pengamatan terhadap kegiatan pembelajaran di kelas. Dalam teknik pengumpulan data, menggunakan pengamatan aktivitas dan pencatatan secara langsung mengenai permasalahan yang ada di sekolah tersebut yang peneliti paparkan pada latar belakang. Pada pembelajaran PTK, yang diukur keberhasilan tidak hanya dari hasil tes, tetapi juga dari proses yang didapat dari hasil observasi. Adapun subjek penelitian yang diamati pada saat observasi, yaitu :

\section{Aktivitas Guru}

Lembar observasi pada aktivitas guru digunakan untuk melihat pelaksanaan pembelajaran yang diadakan guru di dalam kelas selama proses pembelajaran 
berlangsung dengan menggunakan model pembelajaran contextual teaching and learning.

\section{Tes}

Tes adalah suatu cara untuk mengadakan penelitian yang berbentuk tugas yang harus dikerjakan peserta didik dalam bentuk 20 soal pilihan berganda tentang materi cahaya dan sifat-sifatnya. Tes tersebut dilakukan untuk mengetahui kemampuan setiap peserta didik.

\section{Uji Kualitas Instrumen}

\section{Uji Validitas Data \& Instrumen}

Agar instumen yang dibuat oleh peneliti dapat dikatakan valid maka dilakukan uji validitas. Validitas dalam penelitian ini dilakukan dengan diuji dan diperiksa validitasnya, sehingga data tersebut dapat dipertanggungjawabkan. Untuk menjamin validitas ini maka semua pertanyaan disusun berdasarkan kajian-kajian teori yang berkaitan dengan permasalahan. Cara yang digunakan untuk mengetahui tingkat validitas instrumen pada penelitian ini adalah menggunakan rumus korelasi product moment, sebagai berikut:

$$
r_{x y}=\frac{n \sum x y-\sum x \sum y}{\sqrt{\left(n \sum x^{2}-\left(\sum x\right)^{2}\right)\left(n \sum y^{2}-\left(\sum y\right)^{2}\right)}}
$$

(Jihad dan Haris 2013: 180)

Keterangan:

$\mathrm{r}_{\mathrm{xy}}=$ Koefisien korelasi antara $\mathrm{X}$ dan $\mathrm{Y}$

$\mathrm{N}=$ Banyak nya peserta tes

$\mathrm{X}=$ Nilai hasil uji coba

$\mathrm{Y}=$ Rata-rata siswa

Interpretasi terhadap nilai koefisien korelasi $\mathrm{r}_{\mathrm{xy}}$ digunakan kriteria berikut ini:
$0,80<r_{x y} \leq 1.00$
: Sangat tinggi
$0,60<r_{x y} \leq 0.80$
: Tinggi
$0,40<r_{x y} \leq 0,60$
: Cukup
$0,20<r_{x y} \leq 0,40$
: Rendah
$r_{x y} \leq 0,20$
: Sangat Rendah

\section{Reliabilitas Tes}

Untuk menguji reliabilitas tes penelitian digunakan rumus KR-20 (Jihad dan Haris, 2012:180), sebagai berikut:

$r_{11}=\left[\frac{n}{n-1}\right]\left[1-\frac{s_{i}^{2}}{s_{t}^{2}}\right]$

Keterangan:

$r_{11}=$ reliabilitas

$\mathrm{n} \quad=$ banyaknya butir soal

$s_{i}^{2} \quad=$ jumlahvarians skor tiap item

$s_{t}^{2}=$ varians skor total

Interprestasi terhadap nilai koefisien $r_{11}$ digunakan kriteria sebagai berikut:

$r_{11} \leq 0,20$

$=$ Reliabilitas sangat rendah

$0,20<r_{11} 0,40$

$=$ Reliabilitas rendah

$0,40<r_{11} 0,70$

$=$ Reliabilitas sedang

$0,70<r_{11} 0,90$

$=$ Reliabilitas tinggi

$0,90<r_{11} 1,00$

$=$ Reliabilitas sangat tinggi 


\section{Analisis Data}

Analisis data digunakan untuk mengetahui berhasil atau tidaknya tindakan yang dilakukan dalam peelitian. Sesuai dengan tujuan penelitian, maka analisis data yang digunakan adalah:

\section{Hasil Pelaksanaan Pembelajaran}

Untuk menganalisis data hasil pelaksanaan pembelajaran tersebut digunakan rumus, sebagai berikut:

\section{a. Aktivitas guru}

Untuk mengetahui pelaksanaan pembelajaran aktivitas guru digunakan rumus (Sahertian, 2010: 61):

$\mathrm{HP}=\frac{\text { Jumla } h \text { hasil observas } i}{\text { Jumla } h \text { butir pengamatan }} X 100 \%$

Tabel 3.7 Kriteria Penelitian dalam Pelaksanaan Pembelajaran Aktivitas Guru (Sahertian, 2010: 60)

\begin{tabular}{|l|l|}
\hline Kriteria Penilaian & Keterangan \\
\hline $81-100 \%$ & Baik Sekali \\
\hline $61-80 \%$ & Baik \\
\hline $41-60 \%$ & Cukup \\
\hline $21-40 \%$ & Kurang \\
\hline $0-20 \%$ & Sangat Kurang \\
\hline
\end{tabular}

\section{b. Aktivitas Siswa}

Untuk mengetahui pelaksanaan pembelajaran aktivitas siswa digunakan rumus (Jihad dan Haris, 2012: 130):

Nilai Siswa $=\frac{\text { Skor perole han }}{\text { Skor maksimal }} \times 100$

Tabel 3.8 Kriteria Penelitian dalam Pelaksanaan Pembelajaran Aktivitas Siswa (Jihad dan Haris, 2012: 131)

\begin{tabular}{|l|l|}
\hline Kriteria Penilaian & Keterangan \\
\hline $10-20$ & Sangat Kurang \\
\hline $30-49$ & Kurang \\
\hline $50-69$ & Cukup \\
\hline $70-89$ & Baik \\
\hline $90-100$ & Sangat Baik \\
\hline
\end{tabular}

\section{Ketuntasan Hasil Belajar Siswa}

\section{a. Ketuntasan Individual}

Kriteria ketuntasan individual jika seorang siswa dikatakan tuntas belajar jika proporsi jawaban benar siswa mencapai nilai KKM yang ditetapkan sekolah yaitu 70 atau memperoleh nilai 70. Rumus untuk menghitung ketuntasan individu adalah (Trianto, 2009:241)

$\mathrm{KB}=\frac{T}{T_{t}} x 100 \%$

Keterangan :

KB : Ketuntasan Belajar

$\mathrm{T} \quad$ : Jumlah skor yang diperoleh siswa

$\mathrm{T}_{\mathrm{t}} \quad$ : Jumlah skor total 


\section{b. Ketuntasan Klasikal}

Tampubolon (2014:166) menyatakan, siswa dikatakan tuntas belajarnya secara klasikal minimal jika dalam kelas tersebut terdapat $75 \%$ siswa yang tuntas mencapai KKM 70. Untuk mengetahui ketuntasan hasil belajar siswa secara klasikal dapat digunakan rumus sebagai berikut:

$P=\frac{\sum \text { siswa yang tuntas belajar }}{\sum \text { siswa }} \times 100 \%$ (Aqib dkk, 2009:41)

Keterangan:

$\begin{array}{ll}\mathrm{P} & \text { : Persentase Ketuntasan } \\ \sum \text { siswa yang tuntas belajar } & \text { : Total Skor Perolehan siswa } \\ \sum \text { siswa } & \text { : Jumlah Siswa }\end{array}$

\section{c. Penilaian Rata-rata}

Peneliti menjumlahkan nilai yang diperoleh siswa. Selanjutnya dibagi dengan jumlah siswa kelas tersebut sehingga diperoleh nilai rata-rata. Nilai rata-rata ini didapat dengan menggunakan rumus sebagai berikut:

$x=\frac{\sum \chi}{\sum N}$. (Aqib dkk, 2009:40)

Keterangan $: \chi \quad=$ nilai rata-rata

$$
\sum \mathrm{N} \quad \begin{aligned}
\Sigma \chi & =\text { jumlah semua nilai siswa } \\
& =\text { jumlah siswa }
\end{aligned}
$$

\section{Indikator Keberhasilan Penelitian}

Untuk menentukan ketercapaian tujuan perlu dirumuskaan indikator keberhasilan tindakan yang diukur secara realistik. Penelitian tindakan kelas dikatakan berhasil bila dilakukan tindakan perbaikan kualitas pembelajaran. Kualitas pembelajaran berdampakterhadap perbaikan hasil belajar siswa. Tampubolon (2014: 55) urutan indikator secara ilmiah disusun kembali menjadi:

1. Indikator keberhasilan kualitas proses pembelajaran minimal 'baik' ( indikator ini untuk tujuan umum dari penelitian).

2. Indikator keberhasilan hasil belajar secara klasikal minimal $75 \%$ dari jumlah siswa yang mencapai KKM yang ditetapkan.

\section{Prosedur penelitian}

Desain Penelitian Tindakan Kelas berupa refleksi awal dan observasi untuk mengidentifikasi permasalahan di dalam kelas, dilanjutkan dengan pelaksanaan Penelitian Tindakan Kelas (PTK) selama 2 siklus. Desain Penelitian Tindakan Kelas yang digunakan oleh peneliti adalah model yang dikemukakan oleh Arikunto, dkk (2010: 16).

\section{HASIL PENELITIAN DAN PEMBAHASAN}

Berdasarkan hasil analisis data selama proses pembelajaran terjadi peningkatan hasil belajar peserta didi dalam pembelajaran IPA materi cahaya dan sifat-sifatnya di kelas V yaitu pada siklus I dengan nilai rata-rata individual adalah 65,37 dan ketuntasan klasikal peserta didik hanya 18 orang $(45 \%)$ dari 40 orang peserta didik dan 22 orang (55\%) peserta didik yang belum tuntas, sedangkan pada siklus II dengan nilai rata-rata individual 82,25 peserta didik yang tuntas sebanyak 34 orang (85\%) dari 40 orang peserta didik dan yang tidak tuntas hanya 6 orang (15\%). 
Berdasarkan dari hasil analisis data yang diperoleh, maka penelitian ini sejalan dengan penelitian relevan yang dilakukan olehFaema Gulo yang berjudul, " Peningkatan Hasil Belajar Matematika dengan Menggunakan Model Pembelajaran Contextual Teaching Learning (CTL) di kelas IV semester II Negeri 071091 Sisobambowo Kecamatan Mandrehe Kabupaten Nias Barat Tahun Pembelajaran 2015/2016". Sebelum menerapkan model pembelajaran Contextual Teaching Learning (CTL) (tes awal) ketuntasan hasil belajar siswa sangat rendah, yaitu hanya mencapai $34,6 \%$ atau 9 orang yang tuntas dari 26 orang siswa. Setelah dilakukan tindakan pada siklus I diperoleh tingkat ketuntasan belajar 57,7\% (sebanyak 15 siswa tuntas) yang berarti secara keseluruhan belum mencapai standar minimal ketuntasan belajar yaitu 75\%. Hasil tes pada siklus II diperoleh tingkat ketuntasan belajar siswa sebesar 84,6\% (sebanyak 22 siswa dari 26 siswa yang tuntas). Hal ini menunjukkan bahwa setelah dilakukan siklus II siswa dapat dinyatakan secara keseluruhan tuntas dan sudah mencapai standar minimal ketuntasan hasil belajar diatas $75 \%$.

Urika Halawa yang berjudul "Meningkatkan Hasil Belajar Siswa Pada Pelajaran Bahasa Indonesia Dengan Menggunakan Metode Contextual Teaching Learning (CTL) di kelas IV SD Negeri 077309 Orahili Huruna Tahun ajaran 2015/2016”. Dari hasil temuan penelitian di atas dapat disimpulkan bahwa hasil tes awal siswa masih memiliki tingkat ketuntasan belajar di bawah $65 \%$, yaitu 29 siswa $(72,5 \%)$ yang belum tuntas dan memiliki tingkat ketuntasan di bawah $65 \%$ dan sebanyak 11 orang $(27,5 \%)$ yang telah tuntas dalam belajar dengan rata-rata kelas 59,25\% sehingga baik secara individu maupun secara klasikal kemampuan awal (pre test) siswa masih tergolong belum tuntas. Pada siklus I terdapat 7 orang siswa $(17,5)$ yang belum tuntas dan sebanyak 33 orang $(82,5 \%)$ yang telah tuntas dalam belajar dengan rata-rata kelas 70,62. Maka dapat diketahui bahwa kemmpuan siswa dalam memahami materi membaca pantun berdasarkan tingkat keberhasilan secara klasikal masih tergolong belum berhasil. Pada siklus ke II sebanyak 38 orang siswa (95\%) yang telah tuntas dalam belajar dan terdapat 2 orang siswa (5\%) yang belum tuntas dalam belajar dengan nilai rata-rata kelas 78,37. Pada siklus I aktivitas belajar siswa pada aspek afektif dan psikomotor tergolong dalam kategori cukup dengan nilai rata-rata 74,02. Sedangkan pada siklus II aktivitas belajar siswa pada aspek afektif dan psikomotor mengalami peningkatan dengan nilai rata-rata 79,75 dengan kategori baik.

Jadi, dengan demikian penggunaan model pembelajaran contextual teaching and learning dapat meningkatkan hasil belajar peserta didik pada mata pelajaran IPA materi sumber daya alam dan lingkungan di kelas V SD Katolik St. Ignatius Medan Tahun Pelajaran 2016/2017.

\section{PENUTUP Simpulan}

Berdasarkan hasil penelitian dan temuan penelitian ini dapat disimpulkan sesuai dengan perumusan masalah bahwa proses pelaksanaan pembelajaran dengan menggunakan model pembelajaran contextual teaching and learning pada mata pelajaran IPA materi cahaya dan sifat-sifatnya dapat meningkatkan hasil belajar peserta didik, dan hipotesis tindakan yang ada pada bab II dapat dibuktikan, yaitu sebagai berikut:

1. Adanya peningkatan hasil belajar IPA pada materi cahaya dan sifat-sifatnya dengan menerapkan model pembelajaran contextual teaching and learning pada peserta didik di kelas V SD Katolik St. Ignatius Medan Tahun Pembelajaran 2016/2017 yaitu siklus I sebesar 43,7 dan ketuntasan klasikal 45\% sedangkan pada siklus II sebesar 
82,25 dan nilai ketuntasan klasikal yaitu $85 \%$. Hal tersebut sesuai dengan kriteria ketuntasan yang sudah ditetapkan.

2. Adanya peningkatan aktivitas peserta didik dalam pembelajaran IPA pada materi cahaya dan sifat-sifatnya dengan menerapkan model pembelajaran contextual teaching and learning di kelas V SD Katolik St. Ignatius Medan yaitu pada siklus I sebesar 62 dan pada siklus II sebesar 84 .

3. Adanya peningkatan aktivitas guru dalam pembelajaran IPA pada materi cahaya dan sifat-sifatnya dengan menerapkan model pembelajaran contextual tesching and learning di kelas V SD Katolik St. Ignatius Medan yaitu pada siklus I sebesar $60 \%$ dan pada siklus II sebesar $94 \%$.

\section{Implikasi}

Hasil yang diperoleh dari penelitian ini menunjukkan bahwa adanya peningkatan hasil belajar peserta didik pada mata pelajaran IPA materi cahaya dan sifat-sifatnya dengan menerapkan model pembelajaran contextual teaching and learning. Hal ini dapat memberikan penjelasan bahwa penggunaan strategi, pendekatan, metode dan model pembelajaran yang tepat dapat meningkatkan hasil belajar peserta didik serta tujuan pembelajaran dapat tercapai. Dengan demikian konsekuensinya apabila guru menggunakan strategi, pendekatan, metode dan modelpembelajaran yang kurang tepat dalam pelaksanaan pembelajaran di kelas maka akan mengakibatkan hasil belajar peserta didik menjadi rendah.

Oleh karena itu, implikasi penelitian ini terhadap pendidikan adalah:

Bagi guru, penerapan model pembelajaran contextual teaching and learning dalam pembelajaran IPA materi cahaya dan sifat-sifatnya dapat digunakan guru sebagai acuan dalam meningkatkan hasil belajar peserta didik.

Bagi peserta didik, model pembelajaran contextual teaching and learning membawa dampak positif dalam meningkatkan hasil belajar peserta didik dan membuat peserta didik lebih aktif dalam mengiikuti pelajaran.

\section{Keterbatasan Penelitian}

Dalam penelitian ini terdapat keterbatasan yang diharapkan akan memberikan kesempatan bagi peneliti yang lainnya untuk melakukan penelitian sejenis yang akan berguna bagi perluasan wawasan keilmuan.

Adapun keterbatasan penelitian ini adalah:

Subjek dan sampel penelitian hanya berasal dari satu sekolah yaitu SD Katolik St. Ignatius Medan, sehingga hasil penelitian ini belum tentu sesuai dengan sekolah lain dan daerah lain yang memiliki karakteristik yang berbeda dengan sekolah yang saat ini di teliti.

Penelitian ini dilakukan dalam waktu yang relatif singkat sehingga hasil belajar peserta didik masih kurang maksimal.

Penelitian ini hanya terbatas pada penerapan model pembelajaran contextual teaching and learning untuk meningkatkan hasil belajar peserta didik pada mata pelajaran IPA materi cahaya dan sifat-sifatnya. Banyak faktor yang mempengaruhi hasil belajar peserta didik misalnya lingkungan sekolah, kemampuan guru, lingkungan masyarakat, keluarga, kesehatan peserta didik, dan kemampuan peserta didik dalam mengikuti pembelajaran

\section{Saran} berikut:

Berdasarkan hasil penelitian yang dilakukan maka peneliti menyarankan sebagai

1. Bagi guru, diharapkan melakukan pengajaran dengan menggunakan model pembelajaran contextual teaching and learning sebagai alternatif dalam kegiatan 
pembelajaran karena model ini dapat meningkatkan hasil belajar peserta didik dalam menerapkan pembelajaran IPA khususnya pada materi cahaya dan sifatsifatnya dan dapat memotivasi peserta didik untuk belajar aktif.

2. Bagi pihaksekolah, agar kiranya dapat menambah pengadaan sarana dan prasarana pelajaran, serta melakukan pelatihan kepada guru-guru tentang penggunaan model pembelajaran yang dapat meningkatkan kemampuan guru sehingga hasil belajar peserta didik dapat ditingkatkan.Penggunaan model pembelajarn contextual teaching and learning hendaknya diterapkan secara berkelanjutan dalam mata pelajaran IPA materi cahaya dan sifat-sifatnya maupun mata pelajaran lainnya.Penggunaan model pembelajarn contextual teaching and learning hendaknya diterapkan secara berkelanjutan dalam mata pelajaran IPA materi cahaya dan sifat-sifatnya maupun mata pelajaran lainnya.

3. Bagi peneliti, berikutnya jika ingin melakukan jenis penelitian yang sama sebaiknya dilaksanakan lebih dari 1 siklus agar tercapai hasil belajar yang lebih efektif dan efisien.

\section{DAFTAR KEPUSTAKAAN}

Aqib, Zainal. Dkk. 2009. Penelitian Tindakan Kelas. Bandung: Yrama Widia.

Arikunto, Suharsimi. 2016. Dasar-dasar Evaluasi Pembelajaran. Jakarta: Bumi Aksara. 2010. Penelitian Tindakan Kelas. Jakarta: Bumi Aksara.

Dimyati dan Mudjiono. 2013. Belajar \& Pembelajaran. Jakarta: Rineka Cipta. Danim, Sudarwan. 2010. Perkembangan Peserta Didik. Bandung: Alfabeta. Hamalik, Oemar. 2014.Kurikulum dan Pembelajaran.Jakarta: Bumi Aksara. Hamdani. 2017. Strategi Belajar Mengajar. Bandung: Pustaka Setia.

Hamruni. 2013. Strategi Pembelajaran. Yogyakarta: Insan Madani. Instarani, Pulungan. 2015. Ensiklopedia Pendidikan. Medan: Media Persada. Istarani. 2012. 58 Model Pembelajaran Inovatif. Medan: Media Persada.

Jihat, Asep dan Abdul Haris. 2013. Evaluasi Pembelajaran. Yogyakarta: Multi Pressindo.

Khairani, Makmur. 2013. Psikologi Pendidikan. Yogyakarta: Aswaja Presindo.

Sahertian, Piet A. 2010. Konsep Dasar dan Teknik Supervisi Pendidikan dalam rangka Pengembangan Sumber Daya Manusia. Jakarta: Rineka Cipta.

Sagala, H Syaiful. 2008. Konsep dan Makna Pembelajaran. Bandung: ALFABETA

Sanjaya, Wina. 2011. Strategi Pembelajaran Berorientasi Standar Proses Pendidikan. Jakarta: Kencana.

Samatowa, Usman. 2016. Pembelajaran IPA di Sekolah Dasar. Jakarta: Indeks

Shoimin, Aris. 2016. 68 Model Pembelajaran Inovati dalam Kurikulum 2013. Yogyakarta: AR- RUZZ Media.

Slameto. 2010. Belajar \& Faktor-faktor yang Mempengaruhinya. Jakarta: Rineka Cipta.

Sudjana, Nana. 2009. Penilaian Hasil Proses Belajar Mengajar. Bandung: PT. Remaja Rosdakarya

Sugiono. 2016. Metode penelitian pendidikan pendekatan kuantitatif, kualitatif dan $R \& D$. Bandung: Alfabeta.

Susanto, Ahmad. 2016. Teori Belajar \& Pembelajaran di Sekolah Dasar. Jakarta: Kencana Prenada Media Group.

Tampubolon, Saur. 2014. Penelitian Tindakan Kelas. Jakarta: Erlangga.

Tim Bina Karya Guru . 2006. Ilmu Pengetahuan Alam. Jakarta.

Trianto. 2011. Mendesain Model Pembelajaran Inovtif-Progresif. Jakarta: Kencana. 
Usman, Mohammad Uzer. 2010. Menjadi Guru Profesional. Bandung: PT Remaja Rosdakarya. 